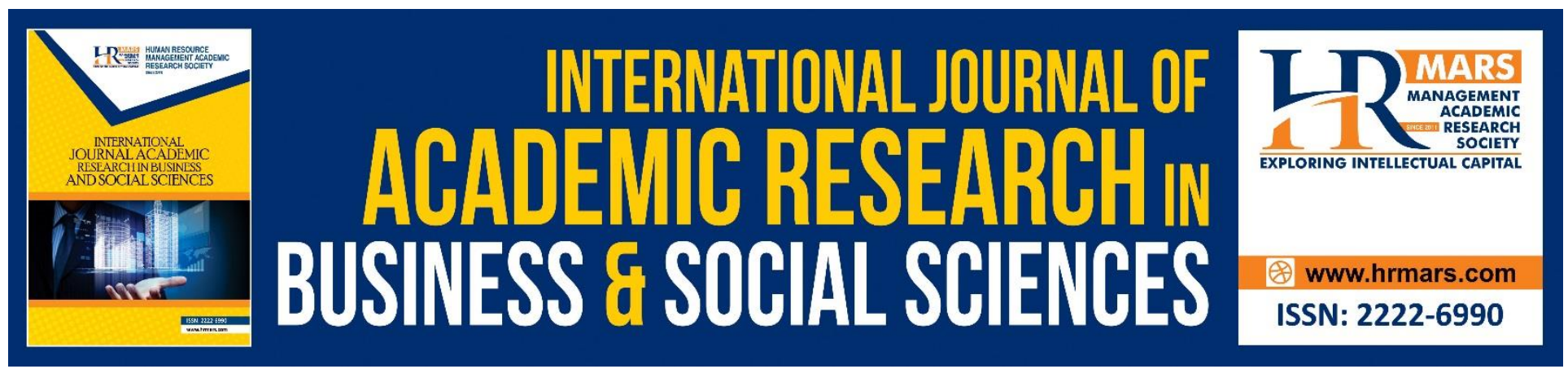

\title{
Entrepreneurial Intention Revisited: The Role Of Entrepreneurial Self-Efficacy
}

\author{
Wan Nor Halimatul Syadiah Wan Yusof, Fakhrul Anwar Zainol, \\ Wan Norhayate Wan Daud
}

To Link this Article: http://dx.doi.org/10.6007/IJARBSS/v8-i12/5209

DOI: $10.6007 /$ IJARBSS/v8-i12/5209

Received: 15 Oct 2018, Revised: 29 Nov 2018, Accepted: 11 Dec 2018

Published Online: 19 Dec 2018

In-Text Citation: (Yusof, Zainol, \& Daud, 2018)

To Cite this Article: Yusof, W. N. H. S. W., Zainol, F. A., \& Daud, W. N. W. (2018). Entrepreneurial Intention Revisited: The Role Of Entrepreneurial Self-Efficacy. International Journal of Academic Research in Business and Social Sciences, 8(12), 95-107.

\section{Copyright: (C) 2018 The Author(s)}

Published by Human Resource Management Academic Research Society (www.hrmars.com)

This article is published under the Creative Commons Attribution (CC BY 4.0) license. Anyone may reproduce, distribute, translate and create derivative works of this article (for both commercial and non-commercial purposes), subject to full attribution to the original publication and authors. The full terms of this license may be seen at: http://creativecommons.org/licences/by/4.0/legalcode

Vol. 8, No. 12, 2018, Pg. 1223 - 1235

http://hrmars.com/index.php/pages/detail/IJARBSS

JOURNAL HOMEPAGE

Full Terms \& Conditions of access and use can be found at http://hrmars.com/index.php/pages/detail/publication-ethics 


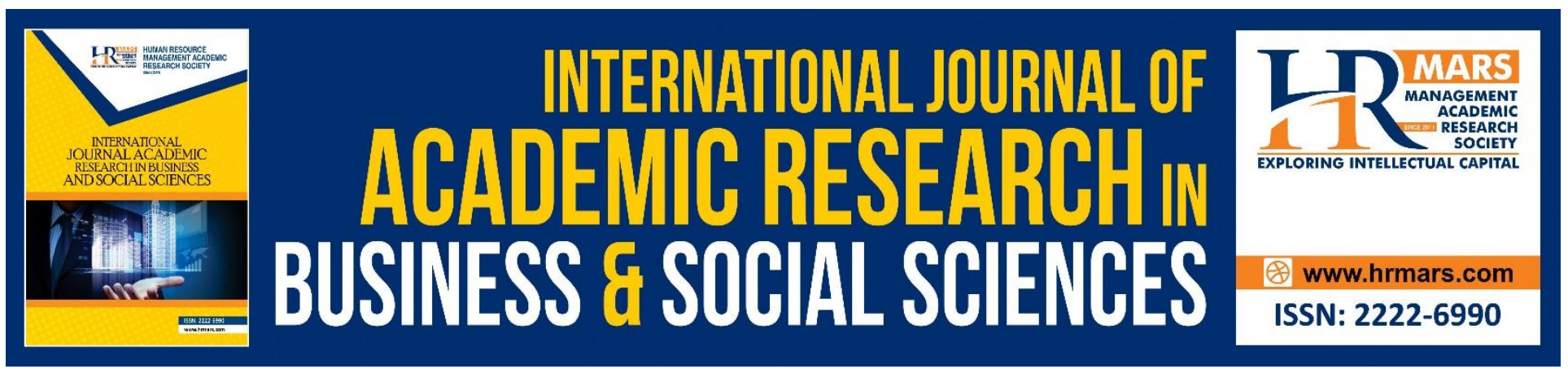

\title{
Entrepreneurial Intention Revisited: The Role Of Entrepreneurial Self-Efficacy
}

\author{
Wan Nor Halimatul Syadiah Wan Yusof, Fakhrul Anwar Zainol, Wan \\ Norhayate Wan Daud
}

Faculty of Economics and Management Sciences, Universiti Sultan Zainal Abidin, 21300 Kuala Nerus, Terengganu, Malaysia.

\begin{abstract}
Entrepreneurship is a key aspect that has often been stressed in the effort to turn Malaysia into a high-income and inclusive developed country. However, producing a successful entrepreneur is not an easy task. The current generation of students has not reached a firm level of self-efficacy. They sometimes easily waver when faced with various forms of challenges and the waves of modernisation. Thus, this study will analyse the relationship between the sources of performance accomplishment self-efficacy and verbal persuasion based on Albert Bandura's Self-Efficacy Theory towards entrepreneurial intention among public university students in Malaysia. It proposes the best predictor variable that encourages public university students in Malaysia to venture into the entrepreneurial field. Using proportionate stratified random sampling, this study sampled 352 respondents from four universities, namely Universiti Utara Malaysia, Universiti Kebangsaan Malaysia, Universiti Malaysia Kelantan, and Universiti Putra Malaysia. The finding of this study shows that entrepreneurial intention is high when performance accomplishment self-efficacy and verbal persuasion efficacy are high. There is a significant relationship between entrepreneurial intention and self-efficacy. It is hoped that this study will be used to assist in outlining entrepreneurship programmes and activities to enhance students' self-efficacy and entrepreneurial intention. The implementation of effective teaching and learning methods is essential in nurturing entrepreneurial potential among public university students in Malaysia.
\end{abstract}

Keywords: Self-Efficacy, Performance Accomplishment, Verbal Persuasion, Entrepreneurial Intention.

\section{INTRODUCTION}

Entrepreneurship is a form of discipline that has become a pillar in the developmental changes and economic growth of a country. Beyond increasing the production and income level per capita, it also acts as a catalyst for increasing the national revenue of a country (Kirby, 2004; Luthje \& Franke, 
2003; Mohd Salleh et al., 2005; Armanurah Mohamad, Nor Aishah Buang \& Muhammad Hussin, 2011).

Based on a study of the previous achievement of the entrepreneurship agenda under the Strategic Plan on Entrepreneurship Development in Higher Education (2013-2015), undeniably, the efforts and initiatives in instilling the entrepreneurial culture, values, and skills among public university students in Malaysia have shown a positive outcome. However, there remains a huge area for improvement that requires attention as the number of public university graduates who have ventured into the entrepreneurial field immediately after graduation remains low at around $2 \%$ of the total number of graduates each year. In line with a statement by the former Deputy Minister of Higher Education, Datuk Dr Mary Yap Kain Ching, the number of entrepreneurs among graduates is still too small at around 3\% compared to the Ministry of Higher Education's main target of $5 \%$ by 2020. Malaysia's achievement in the aspect of entrepreneurial intention remains low, as shown in Figure 1 (UNIRAZAK, 2015) below on the percentage of individuals expected to start a business within the next three years and the rate of Total Early-Stage Entrepreneurial Activity (TEA), which is the percentage of individuals in the process of starting a business as well as those who have been in business for less than three and a half years.

Figure 1: Entrepreneurial Intention and Total Early-Stage Entrepreneurial Activity (TEA) Rates in Six ASEAN Countries in 2014.

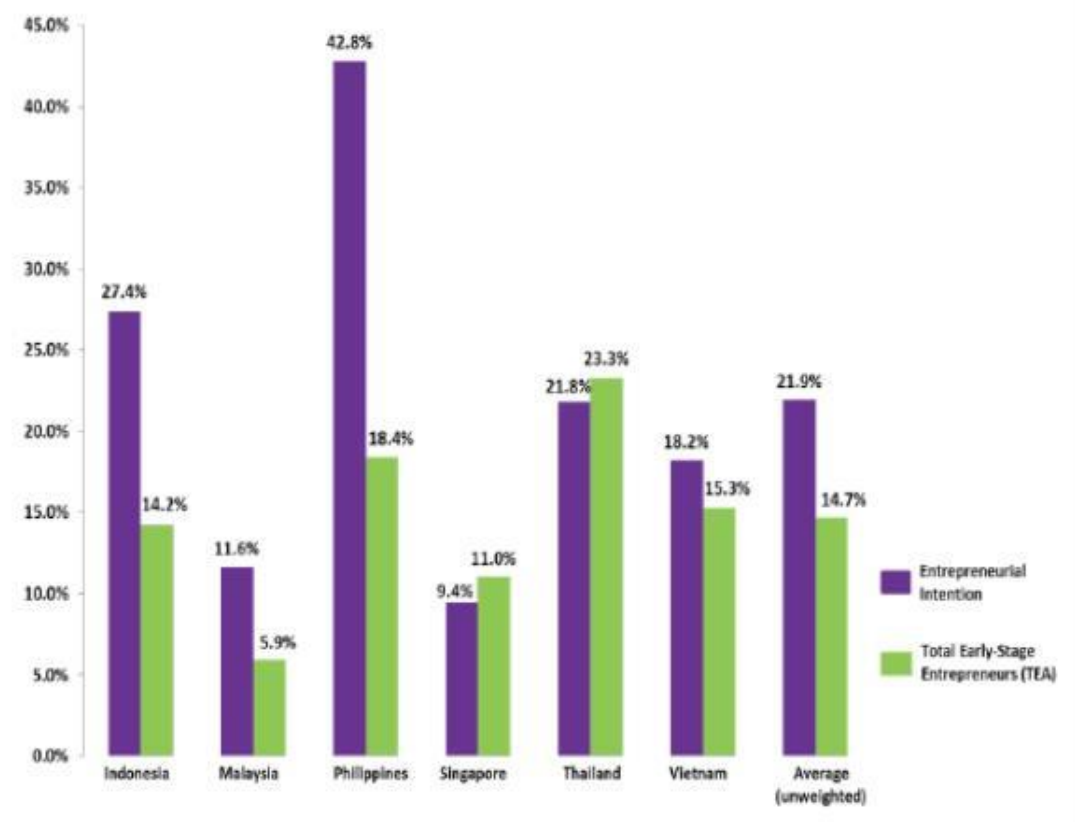

Source: UNIRAZAK (2015)

In Malaysia, the rates might get worse if this situation is not handled properly. Generally, public universities have a role in carrying out continuous entrepreneurship education through various programmes including providing infrastructures, financial support, and several improvements in ensuring that students' entrepreneurial intention can be shaped from an early stage. However, findings by Hoe (2006), Nor Aishah et al. (2010), and Norasmah and Salmah (2011) have proven that various programmes and activities implemented by the government to attract the interest of 
graduates into entrepreneurship have failed as the number of graduates venturing into the entrepreneurial field remains at a low level.

A previous study conducted by Boyd and Vozikis (1994), which developed the self-efficacy theoretical model, had proven that self-efficacy is an important factor in determining entrepreneurial intention and behaviour. Meanwhile, CC Chen, Greene, and Crick (1998) gave empirical evidence that self-efficacy, defined as the students' confidence in their innate ability to organise and implement cognitive, behavioural, and social skills, have a positive impact towards the tendency to start their own business. In view that the effort to produce successful entrepreneurs is not an easy task, entrepreneurship acculturation requires commitment, dedication, resolution, and continuous practice in the practical application of the entrepreneurship spirit within the individual. Thus, this study will look at how Albert Bandura's sources of performance accomplishment self-efficacy and verbal persuasion efficacy can give a positive effect on the intention of public university students to venture into the entrepreneurial field.

\section{Objectives}

The specific aims of this study are as follow:

1. To analyse the relationship between the sources of performance accomplishment self-efficacy and verbal persuasion towards entrepreneurial intention among public university students in Malaysia.

2. To propose the best predictor that encourages public university students in Malaysia to venture into the entrepreneurial field.

\section{Justification for the Study}

The result of this study can be used by the Ministry of Education Malaysia as guidance in outlining and implementing appropriate entrepreneurial programmes at the public universities for the benefit of the students. Apart from that, the top management of the public universities will receive input for outlining new strategies and intensifying their efforts in terms of providing more realistic infrastructural facilities to the students to encourage them to venture into the entrepreneurial field. The group of enablers comprising academics and administrators can ascertain the teaching and learning methods for the public university students that use a more effective psychological approach in ensuring the continuous growth of entrepreneurship development among the students. Researchers and academics will also benefit from the findings of this study in various contexts. Initially, this theory was used by Bandura and colleagues to treat some clinical problems such as phobia, behaviour, cigarettes smoking, and assertive behaviour. Given the multiple uses of this concept, it has since been expanded to the domain of the study of attitudes towards career. Thus, this study will develop a new model of entrepreneurship to provide new understanding and knowledge in the relationship of performance accomplishment self-efficacy and verbal persuasion efficacy towards entrepreneurial intention among public university students in Malaysia. 
INTERNATIONAL JOURNAL OF ACADEMIC RESEARCH IN BUSINESS AND SOCIAL SCIENCES

Vol. 8, No. 12, Dec, 2018, E-ISSN: 2222-6990 @ 2018 HRMARS

\section{LITERATURE REVIEW}

\section{Entrepreneurial Intention}

Entrepreneurial intention has several meanings. According to Card (1988), entrepreneurial intention is defined as a state of mind that directs the attention of a person towards a specific object or path for a certain achievement. It also refers to the level of an individual's tendency to start a project. Crant (1996) associates entrepreneurial intention with the judgement made by the individual to own a business. Davidson (1995) defines entrepreneurial intention as an individual's belief that entrepreneurship is the best career alternative. Entrepreneurial intention is seen as central for understanding the entrepreneurship process. It is easier for an empirical study on intention to generate less biased results compared to an actual study on entrepreneurial behaviour which inherits a biased decision (Krueger, 1993). The economic-psychological model developed by Davidson (1995) in identifying entrepreneurial intention clearly shows that intention is related to the entrepreneurial field.

According to Kristiansen and Indarti (2004), there are differences in entrepreneurial intention among students in Indonesia and Norway, which have economic and cultural differences. They found that entrepreneurial intention among the Indonesian students is significantly higher compared to the Norwegian students. They attributed this situation to the low unemployment rates in Norway that lead to the low intention for self-employment. However, Indonesia's lower economic achievement has led to a higher rate of unemployment, which resulted in an increased intention to do business, even on a small scale. Based on previous studies, more attention should be given to the study of entrepreneurial intention and attitude in the context of regional and country differences because research in this field is still lacking. In other words, entrepreneurial intention is described as a motivating factor that influences individuals to pursue entrepreneurial endeavours. Entrepreneurial intention clearly shows a belief in the ability to organise and implement cognitive, behavioural, and social skills needed to achieve success in a particular matter (Bandura, 1986; Schunk, 1999; Zimmerman, 1989). Based on previous studies, it is clear that an in-depth study on entrepreneurial intention among public university students is required to provide a long-term motivation that can attract students' interest in the entrepreneurial field.

\section{Self-Efficacy}

Bandura (1995) describes self-efficacy as a belief in one's ability to organise and implement an act that is required for handling various situations. The basic principle of the self-efficacy theory is that an individual's accomplishment and motivation are determined through self-belief (Bandura, 1982). Individuals are more likely to engage in activities that they have high self-efficacy compared to other activities (Van der Bijl \& Shortridge-Baggett, 2002). A firm belief in own ability inspires motivation and behaviour to act so that particular aspirations and goals can be accomplished. Selfefficacy and surroundings factor correlate with each other. Individuals who get support from family and friends have a higher self-efficacy compared to those who do not receive social support (Ayodele \& Olanrewaju, 2013). Self-efficacy is also examined with the internal locus of control variable (Hermawan, Soetjipto \& Rahayu, 2016). The result of the study shows that entrepreneurship education should instil aspects of self-efficacy and internal locus of control in students to foster a higher interest in entrepreneurship among the students. 
INTERNATIONAL JOURNAL OF ACADEMIC RESEARCH IN BUSINESS AND SOCIAL SCIENCES

Vol. 8, No. 12, Dec, 2018, E-ISSN: 2222-6990 @ 2018 HRMARS

\section{Performance Accomplishment}

Earlier studies on self-efficacy have proven that performance accomplishment experienced in the past is the best predictor and the most important influence for future accomplishments (Bandura, 1986; Chase et al., 1994; Feltz \& Weiss, 1982; Horn \& Hasbrook, 1987; Locke et al., 1984). This factor is based on direct experiences of individuals. When a person has experienced success in the past, this success can increase the person's self-efficacy. For example, a student who has previously attended formal or informal courses such as entrepreneurial courses, classes or workshops as well as performing well and mastering the contents of the courses will be more efficacious in performing his/her tasks. This statement is supported by Ceren. T (2005), that is, an individual's self-efficacy will increase if he works according to the field and can master the task. Achievements will bring the individual to a higher level of self-efficacy, while failures will lead to lower self-efficacy. The experience of success will increase self-efficacy and interest in the job, but failure in performing the job will lead to the reverse.

The study conducted by Teng Lung Kiu (2006) proves that a teacher's level of self-efficacy predicts the "teacher burnout" phenomenon, which is the reason for teachers' early retirement. Positive and negative experiences will influence an individual's ability in performing the entrusted tasks. When someone demonstrates good performance in the previous task, he will be more efficient and excellent at performing his new task (Bandura, 1977). Besides, knowledge and skills possessed will influence the choice of their action. Individuals interpret accomplishment or success achieved based on their assessment of the possessed quality of knowledge and skills only. For instance, an excellent student will receive a grade $B$ result with disappointment, while a low-performance student will receive a grade $B$ with joy. The grade $B$ result may give a negative effect on the excellent student's confidence, and in contrast, increase the underperforming student's confidence. Future performance and accomplishment depend on an individual's self-efficacy. An individual's self-efficacy would increase and become positive if successes were often achieved in the past, while self-efficacy would decrease and become negative following past failures. From the beginning, the pioneer of social cognitive theory, Albert Bandura, has linked the notion of self-efficacy and performance accomplishment of an individual. In his book, Bandura reported that based on a study conducted, there is a significant relationship between self-efficacy and the accomplishment of job performance (Bandura, 1977). Meanwhile, a study conducted by Stadjkovic, A. D. and Luthans, F. (1998) which conducted a synthesis of 114 empirical studies, found a relationship between self-efficacy and performance accomplishment. A study conducted by Norasmah (2009) and Rohaila et al. (2007) gave evidence that accomplishment is closely related to entrepreneurial intention, by not only enhancing individual cognitive skills but even developing behavioural skills. Based on the discussion above, this study expects that performance accomplishment will influence entrepreneurial intention.

\section{Verbal Persuasion}

Verbal persuasion is self-efficacy that strengthens an individual's confidence through statements made by others who believe that the individual can achieve what he desires. According to Bandura (1986), individuals directed with cues, advice, and guidance can enhance the performance of their abilities such that the individuals will achieve their desired objectives. The level of self-efficacy will increase when a respected person states with full confidence that the individual can handle the 
INTERNATIONAL JOURNAL OF ACADEMIC RESEARCH IN BUSINESS AND SOCIAL SCIENCES Vol. 8, No. 12, Dec, 2018, E-ISSN: 2222-6990 @ 2018 HRMARS

situation well with great success. Students' satisfaction towards a particular field or teaching programme is the internal factor that can increase interest and motivation to remain in their study and next, the student is able to perform the task successfully (Park \& Choi, 2008). An example of verbal persuasion among students is that students will be more motivated and have higher selfefficacy to venture into the entrepreneurial field when the lecturer gives constant encouragement, lifts up the spirit, and inspires confidence that they can succeed based on their ability. Redmond (2010) states that self-efficacy is influenced by verbal persuasion, namely, criticism or encouragement given to the individual's performance. An individual will strive to carry out his or her responsibility and have a higher chance of success when verbal persuasion is used positively. According to Zahra, Jennings, and Kuratko (1999), when individuals take verbal persuasion into consideration in their daily lives, culture will serve to determine their attitudes towards entrepreneurship. Based on the discussion above, this study expects that verbal persuasion will influence entrepreneurial intention.

\section{CONCEPTUAL FRAMEWORK}

Figure 1: Proposed Conceptual Framework

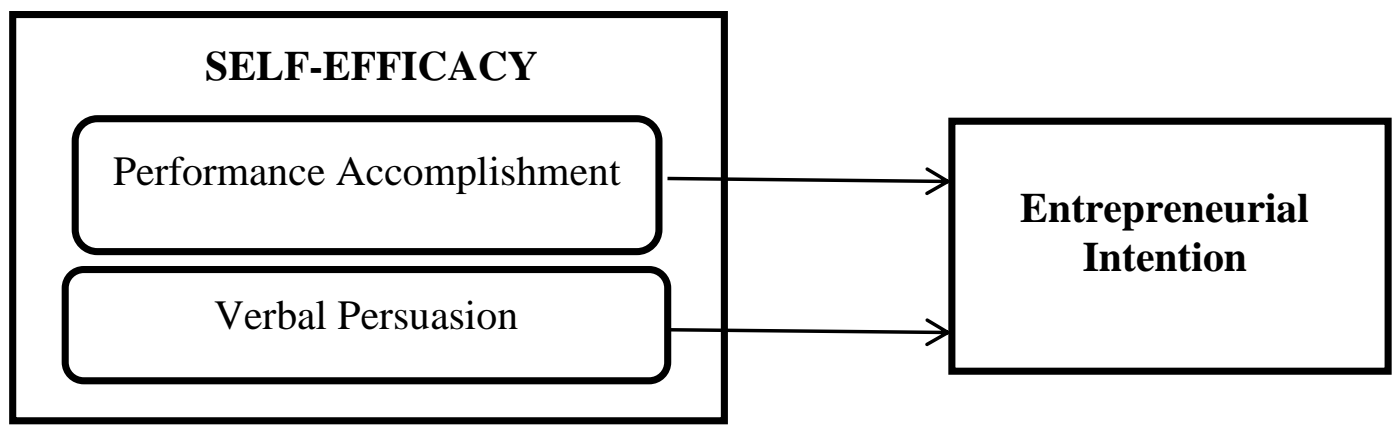

Bandura's Social Cognitive Theory (2009) explains that self-efficacy is the ability to perform a particular behaviour that acts as an indicator of performance, intention, and effectiveness of the task. In the context of entrepreneurship, self-efficacy influences entrepreneurial intention, while entrepreneurial intention determines entrepreneurial behaviour. According to Harris and Gibson (2008) in Buerah and Zoolhilmi (2015), someone who receives positive feedback regarding his or her self-ability or entrepreneurial potential has a higher entrepreneurial intention. Thus, a study on students' self-efficacy and entrepreneurial intention is relevant and significant.

The hypotheses seek to analyse the relationship between the independent variables, namely performance accomplishment and verbal persuasion, and the dependent variable, namely entrepreneurial intention among public university students in Malaysia:

H1: There is a significant and positive relationship between performance accomplishment self-efficacy and entrepreneurial intention.

H2: There is a significant and positive relationship between verbal persuasion self-efficacy and entrepreneurial intention. 
INTERNATIONAL JOURNAL OF ACADEMIC RESEARCH IN BUSINESS AND SOCIAL SCIENCES

Vol. 8, No. 12, Dec, 2018, E-ISSN: 2222-6990 C 2018 HRMARS

\section{METHODOLOGY}

This study implemented a cross-sectional design and adopted a quantitative approach by using structured questionnaires. Two phases were involved in the method of analysis: (1) descriptive statistics to clarify the profile of the respondents and (2) inferential statistics to generalise beyond the data to find patterns that exist in the target population. The population of the study includes all public university students in Peninsular Malaysia who have attended entrepreneurial courses. A total of 5782 students (based on the entrance record for September 2013/2014 session) from four universities, namely Universiti Kebangsaan Malaysia (UKM), Universiti Utara Malaysia (UUM), Universiti Malaysia Kelantan (UMK), and Universiti Putra Malaysia (UPM) were selected as the sample for the study. Only the final year students were selected as respondents. The unit of analysis is the individual public university student in Malaysia.

Table 1: Population and Sample Size by University

\begin{tabular}{llll}
\hline Name of University & Population & Percentage & Total \\
\hline Universiti Kebangsaan Malaysia & 1442 & $22 \%$ & 79 \\
Universiti Pertanian Malaysia & 1154 & $25 \%$ & 90 \\
Universiti Utara Malaysia & 1901 & $20 \%$ & 71 \\
Universiti Malaysia Kelantan & 1285 & $33 \%$ & 117 \\
\hline Total & 5782 & $100 \%$ & 357 \\
\hline
\end{tabular}

Using proportionate stratified random sampling, a total of 500 questionnaires were distributed to the respondents. Based on the table provided by Krejcie and Morgan (1970) on generalised scientific guidelines for sample size decisions (Chua, 2006), only 357 of the 5782 public university students were needed as the sample in this study. Therefore, the 500 questionnaires were divided among the universities to avoid bias and error while answering the questions. Consequently, the 500 questionnaires were distributed to four universities, namely, UUM, UKM, UMK, and UPM.

\section{FINDINGS AND DISCUSSION}

Four public universities were involved in the data collection. A total of 352 questionnaires were answered fully and returned. The information about the distribution of the questionnaires is summarised in Table 2. 
INTERNATIONAL JOURNAL OF ACADEMIC RESEARCH IN BUSINESS AND SOCIAL SCIENCES

Vol. 8, No. 12, Dec, 2018, E-ISSN: 2222-6990 @ 2018 HRMARS

Table 2: Response Rate

\begin{tabular}{ll}
\hline Items & No. of Questionnaires \\
\hline Total questionnaires distributed & 500 \\
Questionnaires returned & 400 \\
Usable questionnaires & 352 \\
Response rate & $70 \%$ \\
\hline
\end{tabular}

Table 3 shows the respondents' profile according to their demographic attributes. Of the 352 respondents selected in this study, 110 or $31.2 \%$ were male and 242 or $68.8 \%$ were female. The highest response rate was from the age range between 21 and 22 years old representing 165 respondents or $46.9 \%$, followed by respondents from the age range between 23 and 24 years old representing 100 respondents or $28.4 \%$. Seventy-one respondents or $20.2 \%$ were below 20 years old, and 16 respondents or $4.5 \%$ were above 25 years old. The three main races that took part in this study were Malay (64.5\%), Chinese (23.3\%), and Indian (8\%). Other races (4.2\%) were also included in the study.

Table 4 shows the correlations for the relationship between the independent variables and dependent variable. Performance accomplishment was significantly associated with entrepreneurial intention at the value of $r=0.175$ and $p<0.001$. This positive relationship suggests that students with high performance accomplishment self-efficacy will have a high level of entrepreneurial intention. Thus, this finding supported H1. Meanwhile, verbal persuasion was also significantly associated with entrepreneurial intention with a value of $r=0.063$ and $p<0.001$. This positive relationship suggests that students who have high verbal persuasion efficacy will have a high entrepreneurial intention. Thus, this finding supported H2. Structural Equation Modelling (SEM) version 22 showed that performance accomplishment and verbal persuasion have a significant relationship with entrepreneurial intention among students at public universities in Malaysia. Meanwhile, verbal persuasion is the predictor variable that influences the students the most to choose the entrepreneurial field in the future. 
INTERNATIONAL JOURNAL OF ACADEMIC RESEARCH IN BUSINESS AND SOCIAL SCIENCES Vol. 8, No. 12, Dec, 2018, E-ISSN: 2222-6990 @ 2018 HRMARS

Table 3: Background of the Respondents

\begin{tabular}{|c|c|c|}
\hline Profile of Respondents & Frequency & Percentage (\%) \\
\hline \multicolumn{3}{|l|}{ Gender } \\
\hline Male & 110 & 31.2 \\
\hline Female & 242 & 68.8 \\
\hline Total & 352 & 100 \\
\hline \multicolumn{3}{|l|}{ Race } \\
\hline Malay & 227 & 64.5 \\
\hline Chinese & 82 & 23.3 \\
\hline Indian & 28 & 8 \\
\hline Others & 15 & 4.2 \\
\hline Total & 352 & 100 \\
\hline \multicolumn{3}{|l|}{ Age } \\
\hline$<20$ years & 71 & 20.2 \\
\hline $21-22$ years & 165 & 46.9 \\
\hline $23-24$ years & 100 & 28.4 \\
\hline 25 and above & 16 & 4.5 \\
\hline Total & 352 & 100 \\
\hline \multicolumn{3}{|l|}{ University } \\
\hline UMK & 117 & 33.4 \\
\hline UUM & 71 & 20.2 \\
\hline UPM & 84 & 23.7 \\
\hline UKM & 80 & 22.7 \\
\hline Total & 352 & 100 \\
\hline
\end{tabular}

Table 4: Output for Regression Weights

\begin{tabular}{llllll}
\hline & Estimate & S.E. & C.R. & P & Hypothesis \\
\hline Ent Intention $\leftarrow--$ PA & 0.175 & 0.56 & 3.129 & $* * *$ & Supported \\
Ent Intention $\leftarrow--$ VP & 0.063 & 0.18 & 3.500 & $* * *$ & Supported \\
\hline
\end{tabular}

Table 5: Summary of Hypotheses Testing

\begin{tabular}{lc}
\hline Hypothesis & Results \\
\hline H1: Performance Accomplishment has a significant relationship with & Accepted \\
Entrepreneurial Intention & \\
H2: Verbal Persuasion has a significant relationship with Entrepreneurial & Accepted \\
Intention & \\
\hline
\end{tabular}


INTERNATIONAL JOURNAL OF ACADEMIC RESEARCH IN BUSINESS AND SOCIAL SCIENCES

Vol. 8, No. 12, Dec, 2018, E-ISSN: 2222-6990 @ 2018 HRMARS

\section{CONCLUSION}

The study aimed to analyse the relationship between performance accomplishment and verbal persuasion towards entrepreneurial intention among public university students in Malaysia and to propose the best predictor that can encourage public university students in Malaysia to venture into the entrepreneurship field. The findings show that verbal persuasion self-efficacy and performance accomplishment self-efficacy have a positive relationship with the entrepreneurial intention of public university students. Entrepreneurship development is an important agenda in ensuring that the national higher education system stays consistently competitive and moves forward according to the latest demand and global trend. It is hoped that the implication of this study will be used by the Ministry of Education Malaysia in improving the policy of the Entrepreneurship Action Plan of Higher Education Institutions 2016-2020 to stress on strengthening the ecosystem in producing higher education graduates with an entrepreneurial mindset and inclined towards entrepreneurship as a career and for creating job opportunities.

Support and commitment from the enablers' group comprising academics and administrators are also emphasised in outlining the strategies that ensure optimum implementation of the public university entrepreneurship agenda. The cooperation from the top management of the public universities needs to be enhanced by reviewing existing policies and regulations to enable public universities to implement strategies that are more pro-entrepreneurs. An example is by increasing the number of programmes based on the psychological approach at public universities. Based on Albert Bandura's Self-Efficacy Theory, it is hoped that public university students can apply all aspects of internal self-confidence by fully exploiting all their capabilities in facing the challenges of globalisation of current knowledge without weary or despair, although they are tested with failures, challenges, and problems, so that they can realise their interests in the entrepreneurial field. If this element is properly inculcated in the entrepreneurial field, it will produce individuals who are ingenious innovators.

Future research can be conducted by adopting a qualitative method or combining two methods incorporating a quantitative and a qualitative study or known as the mixed method. The mixed study can explore in depth how self-efficacy can grow internally within oneself and give firm support for a particular issue, argument, or finding derived from various perspectives whether quantitative or qualitative. It would be interesting to conduct the study on entrepreneurial intention by applying self-efficacy as an independent variable in a comparison between public university students who have attended entrepreneurial courses and those who have not. This type of study will produce more comprehensive outcomes.

\section{REFERENCES}

Armanurah, M., Buang, N. A. \& Hussin, M. (2011). Proses Pengukuran Jenis Jaringan Keusahawanan Dan Implikasinya Terhadap Kelestarian Perniagaan Dalam Kalangan Mahasiswa Yang Berniaga Di Universiti Utara Malaysia. DIm. (pnyt.). Keusahawanan Pemangkin Kecemerlangan Dan Kelestarian Hidup, hlm.131148. Bangi.

Bandura, A. (1986). Social Foundations of Thought and Action. Englewood Cliffs. NJ: Prentice Hall. Boyd, N.G. \& Vozikis, G.S. (1994). The Influence of Self-efficacy on the Development of 
INTERNATIONAL JOURNAL OF ACADEMIC RESEARCH IN BUSINESS AND SOCIAL SCIENCES Vol. 8, No. 12, Dec, 2018, E-ISSN: 2222-6990 @ 2018 HRMARS

Entrepreneurial Intentions and Actions. Entrepreneurship Theory and Practice, 18(4), 63-77.

Chen, C. C., Greene, P. G., \& Crick, A. (1998). Does entrepreneurial self-efficacy distinguish entrepreneurs from managers? Journal of Business Venturing, 13, 295-316.

Crant, J.M. (1996) The proactive personality scale as a predictor of entrepreneurial intentions, Journal of Small Business Management, 34, 3, 42-49.

Davidsson, P. (1995). Determinants of Entrepreneurial Intentions. Working Paper presented at RENT IX Workshop, Piacenza, Italy, November 23-24, 1995.

Harris, M.L.\& Gibson,S.G. 2008. Examining the entrepreneurial Attitudes of US business students.Education\& Training. 50 (7):68-581 www.emeraldinsight.com/0040-0912.htm.Tarikh capaian: 28 Disember 2017.

Hermawan, R.W., Soetjipto, B.E. \& Rahayu, W.P. 2016. The effect of entrepreneurial selfefficacy and locus of control on entrepreneurship interest through entrepreneurship literacy. Journal of Business Management 18(2): 141- 148.

Krueger, N.F. \& Carsrud, A.L. (1993). Entrepreneurial intentions: Applying the theory of planned behaviour. Entrepreneurship \& Regional Development, 5, 315-330.

Kristiansen, S., \& Indarti, N. (2004). Entrepreneurial Intention among Indonesian and Norwegian Students. Journal of Enterprising Culture, 12, 55-78.

Kirby, D.A. (2004). Entrepreneurship education: can business schools meet the challenge? Education \& Training. 46(8/9):510-519.

Krejcie, R.V., \& Morgan, D.W. (1970). Determining Sample Size for Research Activities. Educational and Psychological Measurement, 30, 607-610

Luthje, C. \& Franke, N. (2003). The 'making' of an entrepreneur: testing a model of entrepreneurial intent among engineering students at MIT. R\&D Management. 33: 135-47.

Mohd Salleh Din, Hoe Chee Hee, Norashidah Hashim, Ooi Yeng Keat, Shuhymee Ahmad, Habshah Bakar, Norita Deraman, Rosli Mahmood, Armanurah Mohamad, Lily Julienti Abu Bakar \& Mohamad Nasri Md Hussain. (2005). Asas Keusahawanan. Kuala Lumpur: Prentice Hall.

Buang, N. A. (2002). Asas keusahawanan. Shah Alam: Penerbit Fajar Bakti Sdn Bhd.

Othman, N. (2009). Pelaksanaan Kaedah Pembelajaran Berasaskan Konsultasi dalam Pembudayaan Keusahawanan. Prosiding Kogress Pengajaran dan Pembelajaran di Awana Porto Malai Langkawi.

Othman, N. \& Ishak, S. (2011). Kecenderungan Terhadap Pemilihan Kerjaya Keusahawanan Mengikut Persepsi Peserta Skim Usahawan Siswa. Jurnal Teknologi 56 (Sains Sosial), Sept. 2011: 47-63. Penerbit UTM Press, Universiti Teknologi Malaysia.

Park, J.H., \& Choi, H.J. (2009). Factors Influencing Adult Learners,, Decision to Drop Out or Persist inOnline Learning. Educational Technology \& Society, 12 (4), 207-217.

Yusof, R., Karim, N. O. F. (2007). Kesan Strategi Pembelajaran Pengalaman Terhadap Pembangunan Kompetensi: Perspektif Pendidikan Perakaunan. Jurnal Teknologi. (Jun): 1-26.

Schunk, D.H. (1985). Participation in goal-setting: Effects on self-efficacy and skills of learning diasabled children. Journal of Special education, 19, 307-317. 
INTERNATIONAL JOURNAL OF ACADEMIC RESEARCH IN BUSINESS AND SOCIAL SCIENCES Vol. 8, No. 12, Dec, 2018, E-ISSN: 2222-6990 @ 2018 HRMARS

Stadjkovic, A. D., \& Luthans, F. (1998). Social cognitive theory and self-efficacy: going beyond traditional motivational and behavioral approaches. Organizational Dynamics. 26(14): 62.

Van der Bijl, J. J., \& Shortridge-Baggett, L. M. (2002). The theory and measurement of the self-efficacy construct. In E. A. Lentz \& L. M. Shortridge-Baggett (Eds.), Self-efficacy in nursing: Research and measurement perspectives (pp. 9-28). New York.

Zimmerman, B.J. (1989). A social cognitive view of self-efficacy related academic learning. Journal of Educational Psychology, 329-339. 